\title{
PENINGKATAN KEMAMPUAN PENALARAN MATEMATIKA SISWA MELALUI PENDEKATAN OPEN-ENDED DI KELAS XI SMA NEGERI 1 SILANGKITANG
}

\author{
Nurafni Afriani ${ }^{1}$, Laili Habibah Pasaribu ${ }^{2}$, Rohani $^{3}$ \\ ${ }^{1}$ Mahasiswa Program Studi Pendidikan Matematika STKIP Labuhanbatu \\ ${ }^{2}$ Dosen Program Studi Pendidikan Matematika STKIP Labuhanbatu \\ ${ }^{3}$ Dosen Program Studi Pendidikan Matematika STKIP Labuhanbatu \\ STKIP Labuhanbatu,JIn. SM. Raja No. 126A, KM, 3.5 Aek Tapa, Rantauprapat \\ Email: nurafniafriani130@gmail.com
}

Diterima (Oktober 2018) dan disetujui (Nopember 2018)

\begin{abstract}
Abstrak
Penelitian ini bertujuan untuk mengetahui apakah terdapat peningkatan kemampuan penalaran matematika siswa memalui pendekatan Open-Ended di kelas XI SMA Negeri 1 Silangkitang Tahun Pembelajaran 2017/2018. Jenis penelitian ini adalah Quasi Eksperimen dengan populasi seluruh siswa kelas XI SMA Negeri 1 Silangkitang yang terdiri dari 5 kelas. Sampel penelitian di ambil 2 kelas yang ditentukan dengan teknik Random Sampling, yaitu kelas XI-IPA-2 dengan menggunakan pendekatan Open-Ended dan kelas XI-IPA-1 dengan menggunakan model pembelajaran konvensional. Instrument yang digunakan dalam penelitian ini adalah tes kemampuan penalaran matematika siswa dalam bentuk essay. Data rata-rata pre-test kelas eksperimen dan kontrol sebesar 37.17 dan 35,87 . Setelah diberikan perlakuan pada masing-masing kelas diperoleh data rata-rata post-test pada kelas Eksperimen sebesar 61.60 dengan dan pada kelas kontrol sebesar 54,93 . Pada hasil pengujian $N$-Gain nilai rata-rata kelas eksperimen sebesar 24,43 dan pada kelas kontrol sebesar 19,07 dengan selisih rata-rata $N$-Gain kelas eksperimen dan kelas kontrol sebesar 5,36 . Pada hasil pengujian hipotesis nilai rata-rata $N$-Gain diperoleh pada taraf signifikan $\alpha=$ $0,05 \mathrm{dan} \mathrm{dk}=58$ nilai signifikan $0.016<0,005$. Dengan demikian berarti Ha diterima yang berarti terdapat peningkatan kemampuan penalaran matematika siswa melalui pendekatan Open-Ended Di Kelas XI SMA Negeri 1 Silangkitang Tahun Pembelajaran 2017/2018.
\end{abstract}

Kata Kunci: Pendekatan Open-Ended, Model Pembelajaran Konvensional, Kemampuan Penalaran Matematika.

\section{PENDAHULUAN}

Salah satu mata pelajaran di sekolah yang dapat mengajarkan siswa untuk melatih penalaran dan berfikir kritis adalah matematika. Matematika merupakan ilmu yang mempunyai ciri-ciri khusus, salah satunya adalah penalaran dalam matematika yang bersifat deduktif aksiomatis yang berkenaan dengan ide-ide, konsep-konsep, dan simbolsimbol yang abstrak serta tersusun secara hierarkis. Matematika bersifat deduktif artinya matematika sebagai sarana untuk berpikir secara deduktif. Untuk itu pengajaran matematika memerlukan cara pengajaran yang dapat mengembangkan penalaran siswa. Melalui cara pengajaran yang dapat mengembangkan penalaran siswa ini diharapkan dapat menciptakan siswa sebagai penerus bangsa yang dapat menguasai matematika dengan baik dan akhirnya nanti mereka dapat menerapkan matematika dalam kehidupan sehari-hari. Peraturan Menteri Pendidikan Nasional Republik Indonesia No. 64 Tahun 2013 tentang standar isi untuk tingkat satuan pendidikan dasar dan menengah menjelaskan bahwa mata pelajaran matematika bertujuan agar peserta didik 
memiliki kompetensi yaitu diantaranya menunjukan sikap logis, kritis, analitis, kreatif, cermat dan teliti, bertanggung jawab, responsif dan tidak mudah menyerah. Matematika merupakan ilmu pasti yang semuanya berkaitan dengan penalaran siswa.

Kemampuan penalaran merupakan salah satu kompetensi dasar matematik disamping pemahaman, komunikasi dan pemecahan masalah. Kemampuan bernalar tidak dapat dipisahkan dari kebenaran materi matematika ketika seseorang mempelajari atau membangun pengetahuan matematika nya. Artinya materi matematika akan lebih mudah dipahami dengan adanya kemampuan penalaran yang baik. Penalaran pun dapat berkembang jika penguasaan materi matematikanya pun baik.

Dalam proses belajar mengajar, banyak pengajar matematika yang mengajarkan prosedur tanpa menjelaskan mengapa prosedur itu tersebut digunakan. Sehingga siswa beranggapan bahwa dalam menyelesaikan masalah, cukup memilih prosedur penyelesaian yang sesuai dengan masalah yang diberikan. Akibatnya, kemampuan penalaran dan berkompetensi strategis siswa tidak berkembang sebagaimana mestinya, sehingga mempengaruhi kualitas belajar siswa yang berdampak pada keefektifan proses pembelajaran dan rendahnya prestasi siswa di sekolah.

Salah satu rendahnya kualitas penalaran siswa dalam matematika adalah dalam pembelajaran matematika, guru terlalu berkosentrasi pada hal-hal yang procedural dan mekanistik seperti pembelajaran berpusat pada guru, konsep matematika sering disampaikan secara informatif, dan siswa dilatih menyelesaikan tanpa pemahaman yang mendalam. Hal ini disebabkan umumnya guru siap mentransfer ilmunya langsung kepada siswa, dengan kata lain guru yang aktif sedangkan siswa pasif selama belajar. Akibatnya proses atau prosedur yang telah dilakukan oleh siswa dalam menyelesaikan soal tersebut kurang atau bahkan tidak mendapat perhatian guru. Padahal perlu disadari bahwa proses penyelesaian masalah merupakan tujuan utama dalam pembelajaran pemecahan masalah matematika.

Berkaitan dengan hal tersebut, setelah peneliti melakukan observasi proses pembelajaran matematika yang dilaksanakan di kelas $X$ di SMA Negeri 1 Silangkitang dengan melakukan wawancara dengan guru matematika kelas $X$ di SMA Negeri 1 Silangkitang yang bernama Eva Anggraini S.Pd ditemukan permasalahan antara lain sebagai berikut : 1). Siswa cenderung kurang mampu dalam menggunakan rumus 2). Kemampuan siswa dalam memahami dan menjawab soal yang diberikan guru masih rendah, 3). Beberapa siswa cenderung bergantung pada guru dan temannya dalam menjawab soal-soal yang diberikan, 4). Siwa tidak aktif pada saat pembelajaran matematika berlangsung. Masalah-masalah tersebut disebabkan karena guru masih menggunakan model pembelajaran konvensional. Masalah lain juga dikarenakan kurangnya minat siswa dalam mempelajari matematika. Siswa cenderung menganggap matematika merupakan ilmu yang sulit. Untuk mengatasi masalah tersebut maka perlu digunakan pembelajaran yang tepat sehingga dapat meningkatkan kemampuan penalaran matematika siswa. Oleh karena itu, guru harus terus berusaha menyusun dan menerapkan berbagai model pembelajaran yang bervariasi agar siswa lebih tertarik dalam pembelajaran matematika. Salah satu upaya dalam menyikapi rendahnya penalaran berfikir matematika siswa bisa ditempuh melalui pemilihan pembelajaran. Pembelajaran yang diharap-kan adalah pembelajaran yang dapat memberikan kesempatan yang luas kepada siswa untuk berfikir serta mengembangkan dan mengkomunikasikan gagasan serta informasi dengan menemukan sendiri atau berinteraksi. Pembelajaran yang dapat menumbuhkan aktifitas pembelajaran yang membimbing siswa dalam penemuan pertanyaan serta jawaban yang dihasilkan terhadapnya sehingga menyebabkan rasa puas atas keberhasilan menemukan jawaban dari permasalahan yang diajukan.

Untuk mencapai tujuan pembelajaran diatas perlulah dicari alternatif pembelajaran yang dapat memberikan kesempatan kepada siswa untuk mengungkapkan ide/gagasan matematika secara optimal serta menumbuhkan penalaran sehingga siswa lebih berfikir dalam belajar matematika. Salah satu model pembelajaran yang diterapkan dalam proses pembelajaran matematika adalah pendekatan Open-ended. Pendekatan pembelajaran Open-ended merupakan salah satu alternatif pilihan pendidik dalam proses pembelajaran untuk mencapai tujuan yang telah ditetapkan. Pendekatan pembelajaran Open-ended merupakan pembelajaran terbuka yang menyajikan permasalahan dengan pemecahan berbagai cara (flexibility) dan solusinya juga bisa beragan (multi jawab, fluency). Pembelajaran ini melatih dan menumbuhkan orisinalitas ide, kreativitas, kognitif tinggi, kritis, komunikasi-interaksi, sharing, keterbukaan, penalaran, dan 
Vol.4, No.2 Nopember 2018

Hal $1-9$

sosialisasi. Berdasarkan uraian di atas maka akan dilaksanakan penelitian yang berjudul

"Peningkatan Kemampuan Penalaran

Matematika Siswa Melalui Pendekatan Open-ended Di Kelas XI SMA Negeri 1 Silangkitang Tahun Pembelajaran 2017/2018".

Kemampuan Penalaran Matematika
Lestari (2016:2) menyatakan bahwa kemampuan penalaran matematika adalah kemampuan memahami pola hubungan di antara dua objek atau lebih berdasarkan aturan, teorema, atau dalil yang telah terbukti kebenarannya. Menurut Ruslan (2013:140141) indikator yang menunjukkan adanya penalaran adalah sebagai berikut:

Tabel 1 Indikator Kemampuan Penalaran Matematika

\begin{tabular}{|c|l|l|}
\hline No & \multicolumn{1}{|c|}{ Penalaran Matematika } & \multicolumn{1}{c|}{ Indikator } \\
\hline 1 & Menyajikan pernyataan matematika. & $\begin{array}{l}\text { Mampu menyajikan pernyataan matematika secara } \\
\text { lisan, tulisan, gambar dan diagram. }\end{array}$ \\
\hline 2 & Mengajukan Dugaan & Mampu menuliskan hal-hal yang ditanyakan. \\
\hline 3 & Melakukan manipulasi matematika. & $\begin{array}{l}\text { Mampu melakukan manipulasi matematika dengan } \\
\text { menyelesaikan soal-soal yang diberikan. }\end{array}$ \\
\hline 4 & Menarik kesimpulan. & $\begin{array}{l}\text { mampu menarik dan } \\
\text { mengeneralisasikan darian pernyataan yang } \\
\text { diberiikan. }\end{array}$ \\
\hline
\end{tabular}

Sumber: Ruslan (2013:140-141)

\section{Pendekatan Open-Ended}

Ruslan (2013:141) mengemukakan pendekatan open-ended berawal dari pandangan bagaimana mengevaluasi kemampuan siswa secara objektif dan berpikir matematika tingkat tinggi. Bentuk-bentuk soal yang diberikan melalui pendekatan Openended terdiri dari tiga bentuk, yaitu : 1). Soal untuk mencari hubungan, 2). Soal mengklasifikasikan, dan 3). Soal untuk mengukur. Adapun langkah-langkah model pembelajaran Open-ended adalah sebagai berikut:

Tabel 2 Langkah-langkah Model Pembelajaran Open-ended

\begin{tabular}{|c|l|c|c|}
\hline Fase & Langkah & Kegiatan guru \\
\hline 1 & Persiapan & Guru menyiapkan recana pelaksanaan pembelajaran \\
& Pelaksanaan & (RPP) dan membuat daftar pertanyaan Open-ended.
\end{tabular}

\section{METODOLOGI PENELITIAN}

Penelitian ini adalah penelitian dengan metode quasi-eksperiment. Penelitian komparatif adalah suatu penelitian yang bersifat membandingkan. Tujuan dari penelitian quasi-eksperiment adalah untuk mengetahui pengaruh atau hubungan sebabakibat dengan cara membandingkan hasil kelompok eksperimen yaitu kelompok yang memperoleh perlakuan pembelajaran matematika yang menggunakan pendekatan Open-ended dengan kelompok kontrol yaitu kelompok yang memperoleh pembelajaran matematika yang menggunakan model 
Vol.4, No.2 Nopember 2018

Hal $1-9$

pembelajaran konvensional. Lokasi penelitian berada di SMA Negeri I Silangkitang, Kabupaten Labuhanbatu Selatan. Adapun waktu penelitian dilaksanakan pada semester I Tahun Pelajaran 2017/2018 pada bulan juli selama 3 kali pertemuan dengan setiap kali pertemuan 2x45 menit. Desain perlakuan dapat dilihat pada Tabel 3.

Tabel 3 Pretest Posttest Control Open-ended Design

\begin{tabular}{|c|c|c|c|}
\hline Kelas & $\begin{array}{c}\text { Tes Awal } \\
\text { (Pretest) }\end{array}$ & Perlakuan & Tes Akhir (Posttest) \\
\hline Eksperimen & $\mathrm{Y}_{1}$ & $\begin{array}{c}\text { Model Pendekatan } \\
\text { Open-ended }\end{array}$ & $\mathrm{Y}_{2}$ \\
\hline Kontrol & $\mathrm{Y}_{1}$ & Model Konvensional & $\mathrm{Y}_{2}$ \\
\hline
\end{tabular}

\section{Keterangan :}

$\mathrm{Y}_{1}$ : tes kemampuan awal kemampuan penalaran matematika sebelum diberikan model pembelajaran

$\mathrm{Y}_{2}$ : tes kemampuan akhir kemampuan penalaran matematika setelah diberikan model pembelajaran

Sampel pada penelitian ini adalah siswa kelas XI IPA 2 yang berjumlah 30 siswa sebagai kelas eksperimen dan siswa kelas XI IPA 1 yang berjumlah 30 siswa sebagai kelas kontrol dengan jumlah seluruh sampel adalah 60 siswa. Instrumen yang digunakan dalam penelitian ini adalah tes kemampuan penalaran matematika sebanyak 5 soal yang digunakan untuk pre-test dan post-test. Analisis pada penelitian ini dibantu menggunakan software SPSS 17, untuk pengujian hipotesis menggunakan uji t yaitu independent sample $t$ test, namun sebelum dilakukan uji t terlebih dahulu dilakukan uji normalitas dengan menggunakan uji Kolmogorov-Smirnov dan homogenitas dengan menggunakan uji Analysis Of Varians (ANOVA).

\section{HASIL DAN PEMBAHASAN PENELITIAN}

Deskripsi Data Pre-Test Kelas Eksperimen dan Kelas Kontrol

Dari hasil penelitian yang dilakukan pada bulan Juli 2017 di SMA Negeri 1 Silangkitang didapatkan data pretest pada kelas eksperimen dan kelas kontrol sebagai berikut:

Tabel 4 Hasil Nilai pre-test Penalaran Matematika Siswa Kelas Eksperimen dan Kelas Kontrol

\begin{tabular}{|c|c|c|c|c|}
\hline \multirow{2}{*}{ No. } & \multirow{2}{*}{ Kategori } & \multirow{2}{*}{ Interval Nilai } & \multicolumn{2}{|c|}{ Frekuensi } \\
\cline { 4 - 5 } & & $54-80$ & - & Konsperimen \\
\hline 1 & Tinggi & $28-53$ & 30 & 30 \\
\hline 2 & Sedang & $1-27$ & 30 siswa & - \\
\hline 3 & Rendah & \multicolumn{2}{|c|}{ Jumlah } & me siswa \\
\hline
\end{tabular}

Berdasarkan tabel diatas terlihat bahwa kemampuan penalaran matematika siswa kelas eksperimen dan kelas kontrol semua memiliki kategori sedang. Nilai hasil tes awal semua siswa kelas ekperimen dan kelas kontrol memiliki interval nilai 28-53.

Tabel 5 Rekapitulasi Hasil Pretest

\begin{tabular}{|c|l|c|c|c|c|c|}
\hline \multirow{2}{*}{ No } & \multirow{2}{*}{ Kelas } & \multirow{2}{*}{$\mathbf{N}$} & \multicolumn{4}{|c|}{ Nilai } \\
\cline { 4 - 7 } & & $\begin{array}{c}\text { Skor } \\
\text { Ideal }\end{array}$ & Skor minimum & Skor maksimum & Rata-Rata \\
\hline 1 & Eksperimen & 30 & 100 & 29 & 48 & 37,17 \\
\hline 2 & Kontrol & 30 & 100 & 29 & 46 & 35,87 \\
\hline
\end{tabular}

Hasil rata-rata pretest yang didapatkan pada kelas eksperimen maupun kelas kontrol dapat dilihat pada diagram batang sebagai berikut : 
Vol.4, No.2 Nopember 2018

Hal $1-9$

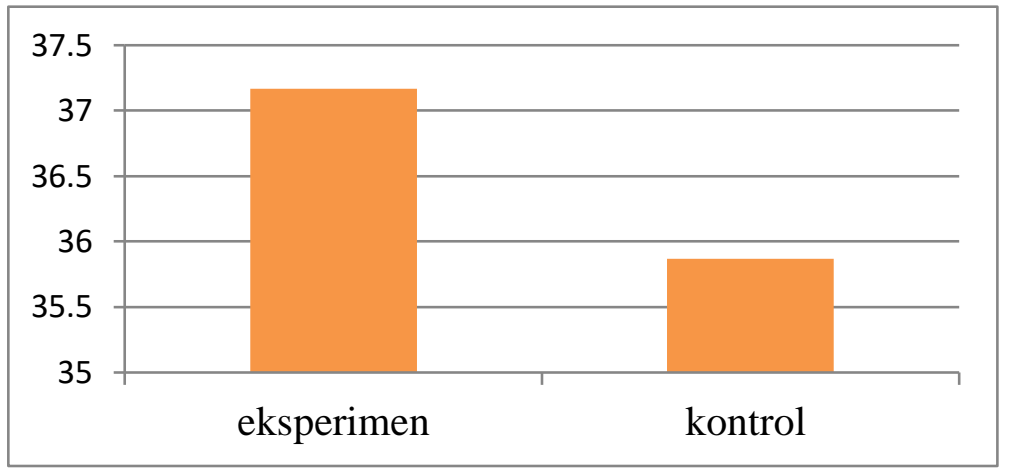

\section{Gambar 1 Diagram Batang Rata-Rata Hasil Pretest Kelas Eksperimen dan Kelas Kontrol}

Berdasarkan diagram batang di atas dapat dilihat rata-rata Pretest kelas eksperimen adalah 37,5 dan kelas kontrol adalah 35,5 .

\section{Deskripsi Data Post-Test Kelas Eksperimen dan Kelas Kontrol}

Dari hasil penelitian yang dilakukan pada bulan Juli 2017 di SMA Negeri 1 Silangkitang didapatkan data posttest pada kelas eksperimen dan kelas kontrol sebagai berikut :

Tabel 6 Hasil Nilai Post-Test Siswa Kelas Eksperimen dan Kelas Kontrol

\begin{tabular}{|c|c|c|c|c|}
\hline \multirow{2}{*}{ No. } & \multirow{2}{*}{ Kategori } & \multirow{2}{*}{ Interval Nilai } & \multicolumn{2}{|c|}{ Frekuensi } \\
\cline { 4 - 5 } & & & Eksperimen & Kontrol \\
\hline 1 & Tinggi & $54-80$ & 27 & 22 \\
\hline 2 & Sedang & $28-53$ & 3 & 8 \\
\hline 3 & Rendah & $1-27$ & - & - \\
\hline \multicolumn{3}{|c}{ Jumlah } & 30 siswa & 30 siswa \\
\hline
\end{tabular}

Berdasarkan tabel diatas terlihat bahwa kemampuam penalaran matematika siswa kelas XI SMA Negeri 1 Silangkitang pada kelas eksperimen 3 orang siswa kategori sedang dan 27 orang siswa kategori tinggi.
Pada kelas eksperimen nilai post-test siswa yang mimiliki nilai berkategori sedang sebanyak 8 orang siswa dan 22 orang siswa yang memiliki nilai berkategori tinggi.

Tabel 7 Rekapitulasi Hasil Posttest

\begin{tabular}{|c|c|c|c|c|c|c|}
\hline \multirow{2}{*}{ No } & \multirow{2}{*}{ Kelas } & \multirow{2}{*}{$\mathbf{N}$} & \multicolumn{3}{|c|}{ Nilai } \\
\cline { 4 - 7 } & & & $\begin{array}{c}\text { Skor } \\
\text { Ideal }\end{array}$ & $\begin{array}{c}\text { Skor } \\
\text { minimum }\end{array}$ & Skor maksimum & Rata-Rata \\
\hline 1 & Eksperimen & 30 & 100 & 48 & 74 & 61,60 \\
\hline 2 & Kontrol & 30 & 100 & 40 & 66 & 54,93 \\
\hline
\end{tabular}

Hasil rata-rata posttest yang didapatkan pada kelas eksperimen maupun

kelas kontrol dapat dilihat pada diagram batang sebagai berikut:

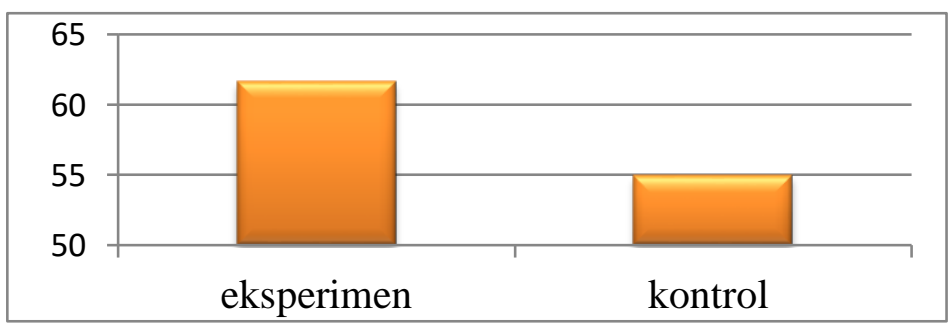

Gambar 2 Diagram Batang Hasil Rata-Rata Nilai Posttest Kelas Eksperimen dan Kelas Kontrol 
Vol.4, No.2 Nopember 2018

Hal $1-9$

Berdasarkan diagram batang di atas dapat dilinat rata-rata Posttest kelas eksperimen adalah 61,60 dan kelas kontrol adalah 54,93 .

\section{Deskripsi Data N-Gain}

Dari hasil penelitian yang dilakukan pada bulan Juli 2017 di SMA Negeri 1 Silangkitang didapatkan data hasil $N$-Gain pada kelas eksperimen dan kelas kontrol sebagai berikut :

Tabel 8 Rekapitulasi Hasil N-Gain

\begin{tabular}{|c|l|c|c|c|c|c|}
\hline \multirow{2}{*}{ No } & \multirow{2}{*}{ Kelas } & \multirow{2}{*}{$\mathbf{N}$} & \multicolumn{4}{|c|}{ Nilai } \\
\cline { 4 - 7 } & & $\begin{array}{c}\text { Skor } \\
\text { Ideal }\end{array}$ & Skor minimum & Skor maksimum & Rata-Rata \\
\hline 1 & Eksperimen & 30 & 100 & 8 & 43 & 24,43 \\
\hline 2 & Kontrol & 30 & 100 & 0 & 32 & 19,07 \\
\hline
\end{tabular}

Berdasarkan data yang diperoleh pada tabel 8 di atas dapat dilihat nilai minimum, nilai maksimum dan rata-rata $N$-Gain kelas eksperimen lebih tinggi dibandingkan dengan kelas kontrol. Dimana nilai minimum pada kelas eksperimen adalah 8 sedangkan pada kelas kontrol adalah 0 . Nilai maksimum pada kelas eksperimen adalah 43 sedangkan pada kelas kontrol adalah 32 . Nilai rata-rata $N$-Gain pada kelas eksperimen adalah 24,43 sedangkan pada kelas kontrol adalah 19,07. Maka dapat disimpulkan bahwa $N$-Gain pada kelas eksperimen lebih tinggi dari pada $N$-Gain kelas kontrol. Dengan selisih rata-rata $\mathrm{N}$-Gain kelas eksperimen dan kontrol adalah 5,36.

Berdasarkan hasil pengujian
normalitas data $\mathrm{N}$-Gain untuk kelas eksperimen dengan menggunakan SPSS diperoleh nilai sig $>$ taraf signifikan $(\alpha=0,05)$ yaitu $0,111>0,05$ dan untuk kelas kontrol diperoleh nilai $\operatorname{sig}>$ taraf signifikan $(\alpha=0,05)$ yaitu $0,161>0,05$, yang artinya bahwa data $N$ Gain kelas kontrol dan eksperimen berdistribusi normal.

$\begin{array}{ccc}\text { Berdasarkan } & \text { hasil pengujian } \\ \text { homogenitas data } & N \text {-Gain } & \text { dengan }\end{array}$ menggunakan SPSS diperoleh nilai $\mathrm{sig}>$ taraf taraf signifikan $(\alpha=0,05)$ yaitu $0,253>0,05$ yang artinya data $\mathrm{N}$-Gain kelas kontrol dan eksperimen homogen atau memiliki varians yang sama.

Berdasarkan hasil pengujian untuk uji-t diperoleh nilai Sig (2-tailed) < taraf taraf signifikan $(\alpha=0,05)$ yaitu $0,016<0,05$. Keputusan yang diperoleh adalah $\mathrm{H}_{0}$ ditolak, maka data miliki nilai signikan yang berbeda. Ini artinya siswa pada kelas eksperimen yang diajarkan melalui pendekatan Open-Ended memiliki kemampuan penalaran matematika yang berbeda dengan siswa kelas kontrol diajarkan melalui model pembelajaran konvensional. Peningkatan kemampuan penalaran ini terlihat dari nilai rata-rata $\mathrm{N}$-Gain kelas eksperimen lebih tinggi dibandingkan dengan kelas kontrol. Nilai rata-rata $N$-Gain pada kelas eksperimen adalah 24,43 sedangkan pada kelas kontrol adalah 19,07. Dengan selisih rata-rata $N$-Gain kelas eksperimen dan kontrol adalah 5,36.

Proses Jawaban Siswa KelasEksperimen dan Kelas Kontrol

\begin{tabular}{|c|c|}
\hline 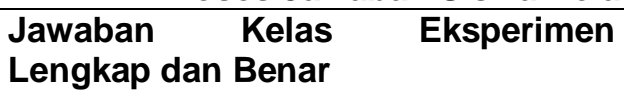 & $\begin{array}{l}\text { Jawaban Kelas Kontrol Lengkap Tetapi } \\
\text { Salah }\end{array}$ \\
\hline 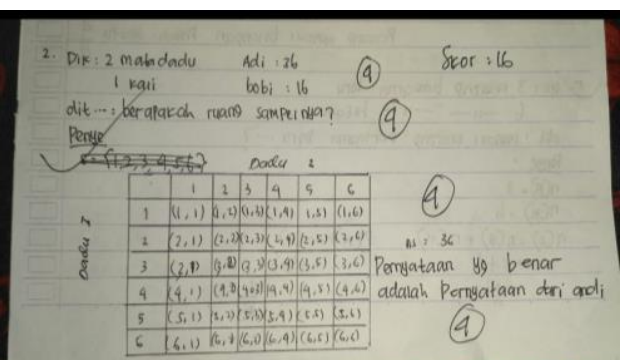 & 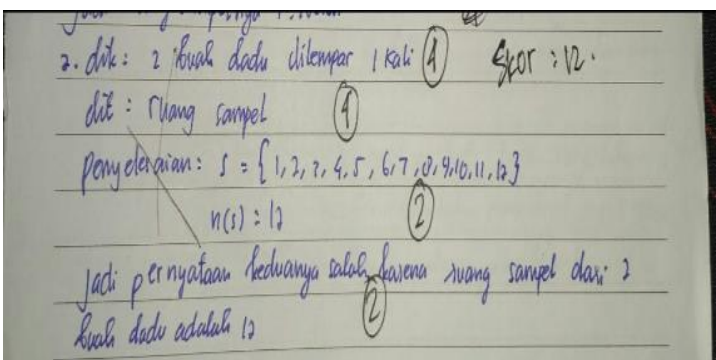 \\
\hline
\end{tabular}

Gambar 3 Proses Jawaban Siswa Kelas Eksperimen dan Kelas Kontrol 
Berdasarkan proses jawaban siswa di atas, ini merupakan hasil proses jawaban siswa pada kelas eksperimen yang pengajarannya dengan menggunakan pendekatan Open-Endeddan kelas kontrol yang diajarkan dengan menggunakan model pembelajaran konvensional. Pada jawaban kelas eksperimen dan kelas kontrol siswa mampu menyajikan pernyataan matematika hal ini terlihat pada gambar proses jawaban siswa kelas eksperimen dan kelas kontrol diatassiswa mampu menuliskan hal-hal yang diketahuidengan benar dan lengkap. Kemudian pada kelas eksperimen dan kelas kontrol siswa mampu mengajukan dugaan matematika hal ini terlihat pada proses jawaban siswa di atas. Siswa kelas eksperimen dan kelas kontrol mampu menuliskan hal-hal yang ditanyakan dari soal LAS di atas. Pada kelas eksperimen siswa mampu melakukan manipulasi matematika hal ini terlihat dari gambar proses jawaban siswa kelas eksprimen di atas siswa kelas eksperimen mampu menyelesaikan soal LAS dengan lengkap dan benar sedangkan pada kelas kontrol siswa mampu menyelesaikan soal dengan lengkap tetapi hasilnya salah. Pada kelas eksperimen siswa mampu menarik kesimpulan dengan benar hal ini terlihat dari proses jawaban siswa kelas eksperimen di atas sedangkan siswa kelas kontrol mampu menyimpulkan jawaban dengan lengkap tetapi hasilnya salah.

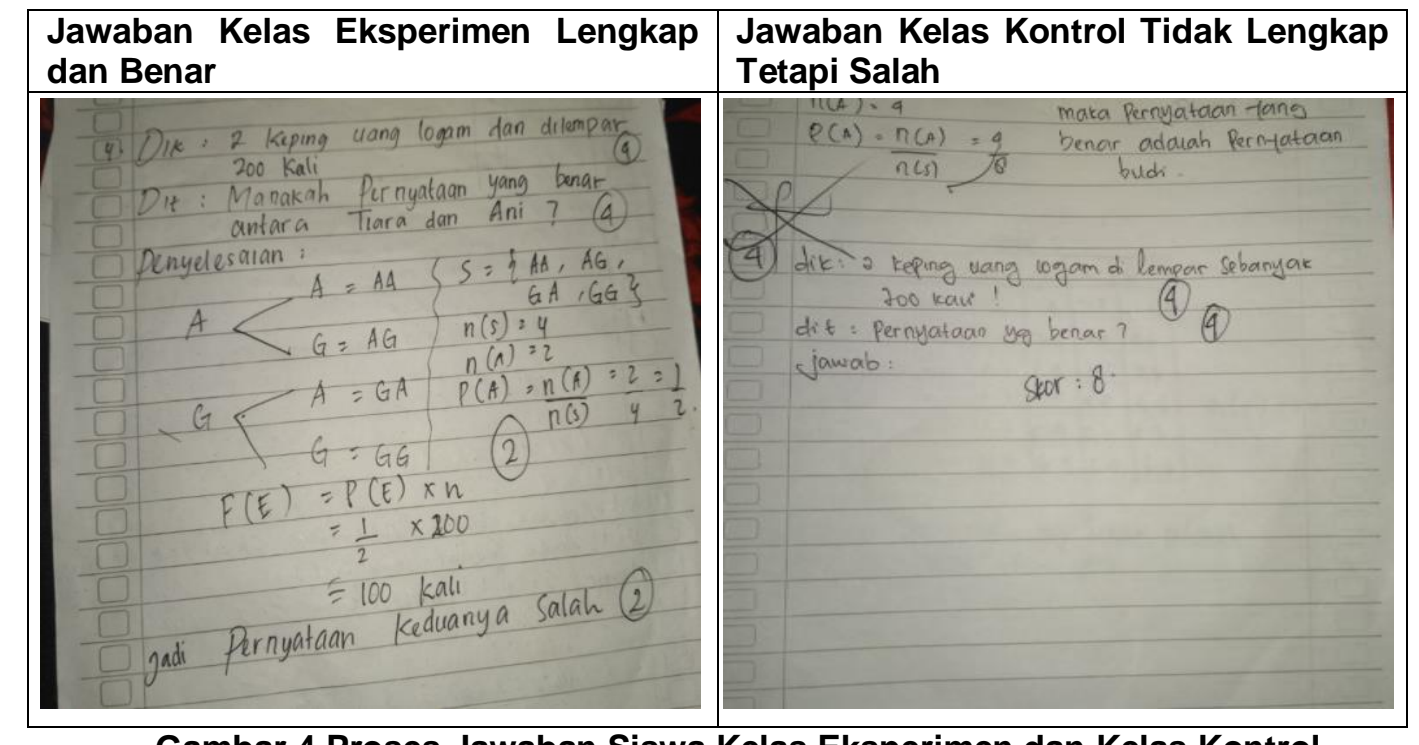

Gambar 4 Proses Jawaban Siswa Kelas Eksperimen dan Kelas Kontrol

Berdasarkan proses jawaban siswa di atas, ini merupakan hasil proses jawaban siswa pada kelas eksperimen yang pengajarannya dengan menggunakan pendekatan Open-Endeddan kelas kontrol yang diajarkan dengan menggunakan model pembelajaran konvensional. Pada jawaban kelas eksperimen dan kelas kontrol siswa mampu menyajikan pernyataan matematika hal ini terlihat pada gambar proses jawaban siswa kelas eksperimen dan kelas kontrol diatassiswa mampu menuliskan hal-hal yang diketahuidengan benar dan lengkap. Kemudian pada kelas eksperimen dan kelas kontrol siswa mampu mengajukan dugaan matematika hal ini terlihat pada proses jawaban siswa di atas. Siswa kelas eksperimen dan kelas kontrol mampu menuliskan hal-hal yang ditanyakan dari soal LAS di atas. Pada kelas eksperimen siswa mampu melakukan manipulasi matematika hal ini terlihat dari gambar proses jawaban siswa kelas eksprimen di atas siswa kelas eksperimen mampu mennyelesaikan soal LAS lengkap dengan hasil salah sedangkan pada kelas kontrol siswa tidak menyelesaikan soal. Pada kelas eksperimen siswa mampu menarik kesimpulan lengkap dengan hasil salah hal ini terlihat dari proses jawaban siswa kelas eksperimen di atas sedangkan siswa kelas kontrol tidak menyimpulkan jawaban.

\section{Pembahasan Penelitian}

Hasil analisis data rata-rata pretest tes kemampuan penalaran matematika siswa kelas XI SMA Negeri 1 Silangkitang tahun pembelajaran 2017/2018 pada kelas eksperimen dan kelas kontrol adalah sebesar 37,17 dan 35,87. Kemudian pada kelas eksperimen siswa diajarkan dengan menggunakan pendekatan Open-Ended 
sehingga peningkatan rata-rata nilai posttest adalah 61,60 . Sedangkan pada kelas kontrol peningkatan rata-rata nilai posttest adalah 54,93. Hasil rata-rata $N$-Gain pada kelas eksperimen sebesar 24,43 sedangkan hasil rata-rata $N$-Gain pada kelas kontrol sebesar 19,07 dengan selisih nilai rata-rata $N$-Gain kelas eksperimen dan kelas kontrol sebesar 5,36 . Maka dapat disimpulkan peningkatan kemampuan penalaran matematikia siswa yang diajarkan dengan pendekatan OpenEnded lebih tinggi dari pada kemampuan penalaran matematika yang diajarkan dengan menggunakan model pembelajaran konvensional.

Untuk menganalisis data pada penelitian ini menggunakan uji-t pada SPSS dengan pengambilan keputusan tolak $\mathrm{H}_{0}$ jika nilai Sig<Taraf Signifikan $(\alpha=0,05)$. Hasil uji-t dimana nilai Sig (2-tailed) untuk data $N$-Gain adalah 0,016. Keputusan yang diperoleh adalah $\mathrm{H}_{0}$ ditolak karena $0,016<0,05$, maka data miliki nilai signikan yang berbeda. Ini artinya siswa pada kelas eksperimen yang diajarkan melalui pendekatan Open-Ended memiliki kemampuan penalaran matematika yang berbeda dengan siswa kelas kontrol diajarkan melalui model pembelajaran konvensional. Dengan hasil pengujian $0,016<0,05$ yang artinya bahwa terdapat peningkatan yang signifikan kemampuan penalaran matematika siswa kelas XI SMA Negeri 1 Silangkitang tahun pembelajaran 2017/2018 pada saat diberi perlakuan.

Hasil penelitian ini juga sejalan dengan hasil penelitian yang dilakukan oleh Ruslan "Pengaruh Pemberian Soal OpenEnded Terhadap Kemampuan Penalaran Matematis Siswa". Pengumpulan data dilakukan melalui tes. Nilai gain diperoleh dari rumus Meltzer dengan hasil: untuk kelas eksperimen nilai gain minimum $=-0,07$ dan maksimum 0,86, sedangkan untuk kelas kontrol nilai gain minimum $=-0,63$ dan maksimum 0,55.

Dalam proses pembelajaran terdapat model serta pendekatan pembelajaran yang mempengaruhi pengembangan kemampuan penalaran matematika siswa dalam belajar matematika di kelas. Berdasarkan hasil proses jawaban siswa terlihat bahwa siswa kelas eksperimen yang diajarkan dengan menggunakan pendekatan pembelajaran Open-Ended dapat menjawab soal sesuai dengan indikator kemampuan penalaran matematika siswa. Pada kelas eksperimen kemampuan siswa dalam menyajikan pernyataan matematika dan mengajukan dugaan matematikalebih tinggi dari pada kemampuan siswa kelas kontrol. Selain itu siswa kelas eksperimen lebih mampu melakukan manipulasi matematika dengan benar. Pada kelas eksperimen kemampuan siswa dalam menarik kesimpulan lebih tinggi dari pada kemampuan siswa kelas kontrol. Berdasarkan hasil proses jawaban siswa yang telah dikerjakan kelas eksperimen dan kelas kontrol terlihat bahwa hasil LAS pada kelas eksperimen lebih baik dari pada hasil LAS kelas kontrol hal ini terlihat dari soal nomor 2 kelas eksperimen mendapatkan hasil skor 16 sedangkn kelas kontrol menadapatkan hasil skor 12. Pada soal nomor 4 kelas eksperimen mendapatkan hasil skor 12 sedangkan kelas kontrol mendapatkan hasil skor 8 .

\section{PENUTUP}

\section{Kesimpulan:}

Terdapat peningkatan kemampuan penalaran matematika siswayang diajarkan dengan menggunakan pendekatan Open Ended pada materi peluang di kelas XI SMA Negeri 1 Silangkitang. Hal ini dapat dibuktikan dari nilai rata-rata $N$-Gain pada kelas eksperimen yang diajarkan dengan pendekatan Open Ended lebih tinggi dari nilai rata-rata kelas kontrol yang diajar dengan metode pembelajaran konvensional $(24,43>19,07)$. Demikian juga berdasarkan hasil perhitungan uji Independent $T$ Test pada nilai $N$-Gain diperoleh nilai Sig. (2tailed) sebesar 0,016. Nilai Sig. (2-tailed) $<0,05$ artinya hasil uji $T$ kelas eksperimen dan kelas kontrol dinyatakan terdapat perbedaan. Jadi dapat disimpulkan bahwa terdapat peningkatan kemampuan penalaran matematika siswa yang diajarkan dengan menggunakan pendekatan Open-Ended.

Proses jawaban siswa dengan menggunakan pendekatan Open-Endedebih tinggi daripada proses jawaban siswa dengan menggunakan model pembelajaran konvensional. Hal ini dapat dilihat dari skor kelas ekperimen yang diajarkan dengan menggunakan pendekatan Open-Ended lebih tinggi dari pada skor kelas kontrol yang diajarkan dengan menggunakan model pembelajaran konvensional.

\section{DAFTAR PUSTAKA}

Wulandari, Enika. (2011). Meningkatkan Kemampuan Penalaran Matematis Melalui Pendekatan Problem Posing Siswa Di Kelas VII A SMP Negeri 2 Yogyakarta. Universitan Negeri Yogyakarta: 2011.

Lestari, Indah. (2016). Peningkatan Kemampuan Penalaran Matematis 
Vol.4, No.2 Nopember 2018

Hal $1-9$

Menggunakan Pendekatan Pendidikan Matematika Realistik. Sekolah Tinggi Keguruan dan IImu Pendidikan Surya. Jurnal Inovasi Pendidikan Dasar, I (2), 1-8,2016.

Ruslan. (2013). Pengaruh Pemberian Soal Open-Ended Terhadap Kemampuan Penalaran Matematis Siswa. Universitan Negeri Semarang, Jurnal Keano, ISSN:2086-2334 Volume 4 Nomor 2 Bulan Desember 2013.

Sri, Tina Sumartini. (2015). Peningkatan Kemampuan Penalaran Matematis Melalui Pembelajaran Berbasis Masalah. Jurnal Pendidikan Matematika Volume 5, Nomor 1, April 2015.

Ariani, Desi. (2014). Pengaruh Implementasi Open-Ended Problem Dalam Pembelajaran Matematika Terhadap Kemampuan Pemecahan Masalah Dengan pengendalian Kemampuan Penalaran Abstak. Universitan Pendidikan Ganesha Singaraja, Indonesia e-journal Program Pascasarjana Universitas Pendidikan Ganesha Program Studi Penelitian dan
Evaluasi Pendidikan (Volume 4 Tahun 2014).

Wahyu, Priyogo Rochmanto. (2014). Pengaruh Pendekatan Open-Ended Terhadap Kemampuan Berfikir Kreatif Matematis Siswa. UIN Syarif Hidayatullah :2014.

Udis, S wiranataputra. (2007). Teori Belajar dan Pembelajaran. Jakarta : Universitas Terbuka Departemen Pendidikan Nasional.

Udhayani, Lovia. (2014). Peningkatan Kemampuan Penalaran Matematika Melalui Strategi Problem Based learning Bagi Siswa SMK. Universitas Muhammadiyah Yogyakarta.

Nursyahidah. (2016). Kemampuan Penalaran Matematis Siswa SMP Dalam Belajar Garis dan Sudut Dengan Geogebra. Universitas PGRI Semarang Suska Journal Of Mathematics Education Vol. 2, No.1, 2016, Hal 13-1. 